\title{
PREVALENCE OF HEPATITIS B AND HEPATITIS C VIRUS IN RAHIM YAR KHAN; A HOSPITAL BASED STUDY.
}

\footnotetext{
1. MBBS, FCPS

Consultant Pathologist CMH Rahim Yar Khan.

2. MBBS, FCPS

Consultant Anesthetics CMH Rahim Yar Khan.

3. MBBS, FCPS

Consultant Pathologist CMH Quetta.

4. MBBS, FCPS

Consultant Pathologist

Armed Forces Institute of Pathology Rawalpindi.

5. MBBS, FCPS

Consultant Pathologist CMH Abbottabad.

6. MBBS

Consultant Pathologist $\mathrm{CMH}$ Thall.
}

\section{Correspondence Address:}

Dr. Muhammad Azam

House No.48B, Nawab Town

Raiwind Road, Lahore.

azam5795@gmail.com

Article received on:

08/01/2020

Accepted for publication:

$15 / 04 / 2020$

\begin{abstract}
Muhammad Zubair ${ }^{1}$, Mohsin Ur Rashid², Muhammad Azam ${ }^{3}$, Hassan Tariq ${ }^{4}$, Syed Salman Ali ${ }^{5}$, Akhtar Ali Bajwa ${ }^{6}$

ABSTRACT... Objectives: This study was performed to determine the prevalence of Hepatitis $B$ and $C$ virus in general population of Rahim Yar Khan. Study Design: Cross Sectional and Observational study. Setting: Combined Military Hospital Rahim Yar Khan. Period: $1^{\text {st }}$ Jan 2018 to $30^{\text {th }}$ June 2019. Material \& Methods: Patients of both genders and all ages were included in the study. HBV and HCV were analysed using Kit method and positive cases confirmed by ELISA. Results: A total number of 4635 people were screened for Hepatitis B, and C. Among 2325 individuals screened for HCV, 365 (15.6\%) were positive for Anti HCV. Among 2310 individuals screened for HBV, 82 (3.5\%) were found positive. Positive cases were later confirmed by ELISA. Conclusion: High prevalence of HBV and HCV in this area warrants serious efforts to prevent the spread of these viruses. Screening facilities should be provided at community level to assess the real burden and for early diagnosis and prevention of complications.
\end{abstract}

Key words: Hepatitis B Virus, Hepatitis C Virus, Screening.

Article Citation: Zubair M, Mohsin Ur Rashid, Azam M, Tariq H, Ali SS, Bajwa AA. Prevalence of Hepatitis B and Hepatitis C Virus in Rahim Yar Khan; A Hospital Based Study. Professional Med J 2020; 27(10):2129-2132. DOI: 10.29309/TPMJ/2020.27.10.4472

\section{INTRODUCTION}

Hepatitis B virus (HBV) and Hepatitis C virus (HCV) infections are responsible for significant morbidity and mortality globally. Prevalence of $\mathrm{HBV}$ is 350 million worldwide, whereas 170 million population is infected with HCV representing $7 \%$ and $3 \%$ of the entire population respectively. ${ }^{1}$ According to World Health Organization (WHO), approximately two billion people are infected with $\mathrm{HBV}$ and 350 million are infected with $\mathrm{HCV}^{2}{ }^{2}$

Disease burden in Asian pacific region is largest around the world, as $74 \%$ of deaths from liver cancer worldwide occur in Asia. ${ }^{3}$ The prevalence of $\mathrm{HCV}$ varies in different countries. According to various studies in Africa it is $6 \%$, Japan $1.5 \%$, USA $0.6 \%$ and in UK it is $0.17 \% .4,5$ Its prevalence is extremely low in Europe, North America and Australia, intermediate in South America, Mediterranean countries and East Europe. Highest prevalence has been reported from Egypt. In india 12-18 million people are infected with $\mathrm{HCV}^{6}$ and approximately 37 million people have HBV infection. ${ }^{7}$ In Pakistan the prevalence varies from $0.7 \%$ to $20 \%$ in different studies at different times. ${ }^{4,8,9}$ Exact seroprevalence could not be established due to lack of nationwide study.

$\mathrm{HBV}$ and HCV are endemic in Pakistan as shown by survey performed by Pakistan Medial research Council. Approximately 12 million people infected with Hepatitis B and C, which estimates to $7.4 \%$ population. Among these $4.9 \%$ are infected with $\mathrm{HCV}$ and $2.4 \%$ are infected with HBV. ${ }^{10}$

Studies showing prevalence of HBV and HCV is easily available from Karachi, Rawalpindi, Abbottabad, Lahore and Faisalabad but limited studies are available from population of South Punjab and Rahim Yar khan. This study will help in determining prevalence of HBV and HCV in population of Rahim Yar Khan.

Hepatits $B$ and $C$ viruses are transmitted through contact with blood and blood products of infected individuals. It is also commonly transmitted vertically from mother to child in endemic areas. ${ }^{11}$ Other reasons for transmission in developing 
countries are use of unsterilized injections and equipment, use of unscreened blood, tattooing and body piercing with infected needles, shaving equipment of barbers, sexual transmission, use of unsterilized equipment for minor surgeries, unsterilized endoscopes, dialysis machines and cystoscopes. These infections are also common in intravenous drug abusers worldwide. Excessive and unsafe use of injections are responsible for approximately 8-16 million HBV cases and 2-5 million HCV cases and 80,000 - 160,000 HIV cases throughout the world. ${ }^{12}$

\section{MATERIAL \& METHODS}

This was a descriptive and cross sectional study carried out at Combined Military Hospital Rahim Yar Khan from 1stJan 2018 to 30 June 2019. Patients were selected by non-probability method of sampling. Both males and females irrespective of their age, socioeconomic status and the individuals previously unscreened were included in the study. Any drug addict with known history of HBV or HCV was excluded from study. Previously positive cases were also excluded from the study. A total of 4635 individuals were included in the study. The persons included comprised patients undergoing screening for surgery, C section or other gynecological procedures, outpatient department patients who were advised investigations for different reasons, newly inducted recruits and blood donors including those in blood donation camps. Data was analyzed using SPSS version 20 . Variables were defined qualitatively and frequency distribution was applied. HBsAg and Anti HCV were tested by Immunochromatographic assay. Positive cases were later confirmed by ELISA.

\section{RESULTS}

A total 4635 individuals were screened for both HBV and HCV. Among these 2325 individuals were screened for $\mathrm{HCV}$ and 2310 individuals for HBV. In individuals screened for HCV 365 (15.6\%) tested positive for Anti-HCV. Among these 29.4\% $(n=98)$ were males while $70.6 \%(n=267)$ were females. Among those screened for HBV 82 (3.5\%) tested positive for HBsAg of which 26 (31.7\%) were male and 56 (68.3\%) were females as shown in table-I and II. Out of all these cases
06 subjects $(0.12 \%)$ were positive for both $\mathrm{HBsAg}$ and Anti-HCV.

\begin{tabular}{|c|c|c|}
\hline & $\operatorname{HCV}(n=2325)$ & HBV $(n=2310)$ \\
\hline Positive & 365 (15.6\%) & 82 (3.5\%) \\
\hline Negative & 1960 (84.4\%) & 2228 (96.5\%) \\
\hline \multicolumn{3}{|c|}{$\begin{array}{l}\text { Table-I. Frequency of reactive and non-reactive cases } \\
\text { of } \mathrm{HBV} \text { and } \mathrm{HCV} .\end{array}$} \\
\hline Gender & $\begin{array}{l}\text { HCV Positive } \\
\qquad(n=365)\end{array}$ & $\begin{array}{l}\text { HBV Positive } \\
\quad(n=82)\end{array}$ \\
\hline Males & $98(29.4 \%)$ & $26(31.7 \%)$ \\
\hline Females & 267 (70.6\%) & $56(68.3 \%)$ \\
\hline \multicolumn{3}{|c|}{$\begin{array}{c}\text { Table-II. Gender distribution of HBV and HCV reactive } \\
\text { cases. }\end{array}$} \\
\hline
\end{tabular}

The results show that prevalence of both $\mathrm{HBV}$ and $\mathrm{HCV}$ was low in age group less than 20 years and it gradually increased between 20 to 40 years and 40 to 60 years. The prevalence in both infections was reduced in individuals above 60 years as shown in Figure-1.

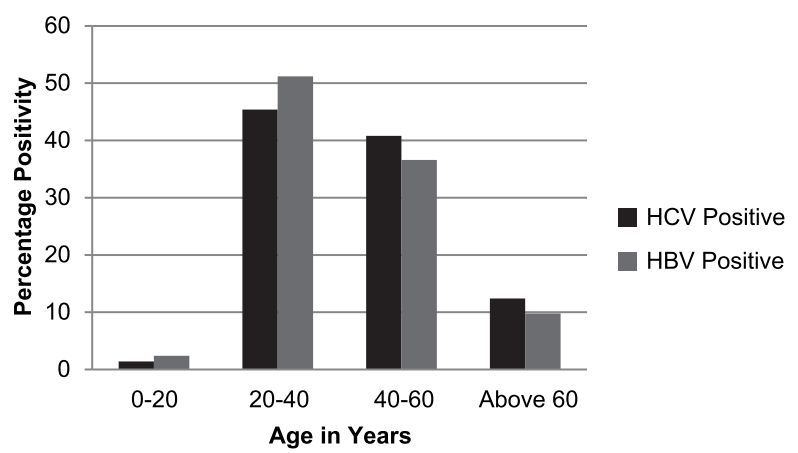

Figure-1. Showing prevalence rate of HBV and HCV in different age groups.

\section{DISCUSSION}

Epidemiological studies are important to assess the disease burden in a community and formulating strategies to prevent transmission of various diseases. $\mathrm{HBV}$ and $\mathrm{HCV}$ are the major cause of morbidity and mortality throughout the world and specifically in Pakistan.

In our study the seroprevalance of HBV and HCV is $3.5 \%$ and $15.6 \%$ respectively. This prevalence is high as compared to other local studies but comparable to that done in south Punjab and Rahim Yar khan district. 
In various studies in Pakistan the prevalence of HCV was found to be $2.2 \%$ in Peshawar ${ }^{13}, 13.8 \%$ in Swat $^{14}, 10.4 \%$ from Rawalpindi ${ }^{15}, 2.89-4.97 \%$ from Lahore ${ }^{16,17}, 3.26 \%$ from Sialkot ${ }^{18}$ and $7.8 \% \%$ from South Punjab ${ }^{19}$, 6.8\% from Karachi ${ }^{20}$, and $1.87 \%$ from Quetta. ${ }^{21}$ In a study done by Hakim A et al 2006 in Rahim Yar khan showed a high prevalence of $\mathrm{HCV} 18.2 \%{ }^{22}$ By analyzing these studies the prevalence of HCV was highest in Rahim Yar Khan (18.2\%) ${ }^{22}$ and Swat (13.8\%). ${ }^{14}$

The reason for such high prevalence in our area is because of low literacy rate, low socioeconomic conditions, poor health care delivery services which results in use of infected instruments and injections by the quacks and in dental procedures.

The seroprevalance of HBV was 3.5\% in our study. Comparing with the studies done in different parts of the country the prevalence of HBV was found to be $1.9 \%$ from Peshawar ${ }^{13}, 3.5 \%$ in Swat ${ }^{14}, 2.7 \%$ from Rawalpindi ${ }^{15}, 2.06-4.3 \%$ from Lahore $^{16,17}$, 7.53\% from Bahawalpur ${ }^{23}$, 2.3\% from South Punjab ${ }^{19}, 5.5 \%$ from Karachi ${ }^{20}$, and $12 \%$ from study in Rahim Yar khan. ${ }^{22}$ The prevalence was highest in Rahim Yar Khan (12\%) ${ }^{22}$ and Bahawalpur $(7.53 \%)^{23}$ The reasons for high prevalence of HBV in this area are similar to as stated for HCV. In addition there as very less awareness regarding the vaccination against $\mathrm{HBV}$.

Due to the high prevalence of HBV and HCV in all over the country and particularly in Rahim Yar khan, it is imperative to formulate strategies at country level to identify these infected individuals. It is evident by these studies that the common causes of infection in all cases is transfusion of unscreened blood and blood products, reuse of used syringes and infected equipment. In addition it can be transmitted by tattooing, ear piercing, circumcision, and barbers due to reuse of infected equipment. Thus efforts should be done to increase awareness among individuals and promote safety behavior among the general public and health care workers for use of screened and sterilized blood and medical instruments. Limitations of my study are that it was a single hospital based study.

\section{CONCLUSION}

Considering the high prevalence of HBV and HCV in Pakistan serious efforts should be made at national level. These include political engagement, increase awareness of general public and early diagnosis, and promoting the vaccination against $\mathrm{HBV}$.

\section{Copyright $\subset 15$ Apr, 2020.}

\section{REFERENCES}

1. Nafees M, Farooq M, Jafferi G. Frequency of Hepatitis $B$ and $\mathbf{C}$ infections in the general population of Lahore, Pakistan. Biomedica. 2009; 25:106-111.

2. Aziz S, Khanani R, Noorulain W, Rajper J. Frequency of Hepatitis B and $\mathbf{C}$ in rural and Periurban Sindh. J Pak Med Assoc. 2010; 60(12):1069-1071.

3. International agency of research against cancer. World cancer report. Geneva: IARC Publications, 2014.

4. Ali N, Nadeem M, Qamar A, Qureshi AH, Ejaz A. Frequency of Hepatitis-C virus antibodies in blood donors in Combined Military Hospital, Quetta. Pak J Med Sci 2003; 19(1):41-4.

5. Ryan KE, Mclennan S, Barber JA, Hewitt P. Follow-up of anti-HCV blood donors. BMJ 1994; 308:696.

6. Dhiman RK. Future of therapy for hepatitis $\mathbf{C}$ in India: A matter of accessibility and affordability? J Clin Exp Hepatol 2014; 4: 85-86.

7. Puri P. Tackling the Hepatitis $B$ disease burden in India. J Clin Exp Hepatol 2014; 4: 312-19.

8. Rahman M, Akhtar G, Lodhi Y. Seroprevalence of Hepatitis $\mathbf{C}$ antibodies in blood donors. Pak $\mathrm{J}$ Med Sci 2002; 18(3):193-6.

9. Alam M, Ahmed D. Prevalence of antibodies to Hepatitis $\mathbf{C}$ virus in blood donors in Sialkot. J Coll Physicians Surg Pak 2001; 11(12):783.

10. Farhat M, Yasmeen A, Ahmad A. An Overview of Hepatitis B and C in Pakistan. International Journal of Microbiology and Allied Sciences (IJOMAS). November 2014, $1(2): 98-102$.

11. Davis LG, Weber D J, Lemon S M. Horizontal transmission of hepatitis B virus. Lancet 1989; 333:889-893 doi: 10.1016/ S0140-6736(89)92876-6. 
12. Kane A, Lloyd J, Zaffran M, Simonsen L, Kane M. Transmission of hepatitis B, hepatitis $C$ and HIV viruses through unsafe injections in the developing world: Model based regional estimates. Bull World Health Organ. 1999; 77:801-807.

13. Ahmad J, Taj AS, Rahim A, Shah A, Rehman M. Frequency of Hepatitis $B$ and Hepatitis $C$ in healthy blood donors of NWFP: A single center experience. J Postgrad Med Inst 2004; 18(3):343-52.

14. Ahmad A, Ahmad B, Ali A, Ahmad Y. Seroprevalence of HbsAg and anti-Hcv in general healthy population of swat district with frequency of different HCV genotypes. Pak J Med Sci Oct - Dec 2009; 25(5):744-8.

15. Gul A, Jamal N, Abbas H. Seropositivity of HBsAg and Anti-HCV in Rawalpindi/Islamabad and analysis of risk factors. Ann. Pak. Inst. Med. Sci. 2009; 5(1): 242244.

16. Shah $\mathrm{NH}$, Shabbier $\mathrm{G}$. A review of published literature on Hepatitis B and $\mathbf{C}$ virus in Pakistan. J Coll Physician Surg Pak 2002; 12(60):368-71.

17. Ahmad S, Gull J, Bano KA, Aftab M, Kokhar MS. Prevalence of anti-Hepatitis $C$ antibodies in healthy blood donors at Services Hospital Lahore. Pakistan Postgrad Med J 2002; 13(1):18-20.
18. Alam M, Ahmed D. Prevalence of antibodies to Hepatitis $\mathbf{C}$ virus in blood donors in Sialkot. J Coll Physicians Surg Pak 2001; 11(12):783.

19. Aslam MN, Nadeem M, Qureshi UF. HEPATITIS B AND C. The Professional Medical Journal. 2016 Jan 10;23(01):025-8. DOI: 10.17957/TPMJ/16.3104.

20. Ahmed MU. Hepatitis B surface antigen study in professional and volunteer blood donors. Ann AbbasiShaheedHosp Karachi Med Dent Coll 2001; 6:304-6.

21. Ali N, Nadeem M, Qamar A, Qureshi AH, Ejaz A. Frequency of Hepatitis-C virus antibodies in blood donors in Combined Military Hospital, Quetta. Pak J Med Sci 2003; 19(1):41-4.

22. Hakeem A, Khan MS, Abdullah M, Rehman MA, Hashmi MI. Prevalence of $\mathrm{HbSAg}$ and anti HCV in pregnant ladies attending antenatal clinic at Sheikh Zayed Medical Complex, Rahim Yar Khan. Esculapio. 2006; 2:8-10.

23. KM, Ali S, Khan AA, Shafique M, Khan MA, Majeed S, et al. Hepatitis B carrier among volunteer blood donor students at Quid-i-Azam Medical College Bhawalpur. Professional Med J 2002; 9(3):186-90.

\begin{tabular}{|c|c|c|c|}
\hline \multicolumn{4}{|c|}{ AUTHORSHIP AND CONTRIBUTION DECLARATION } \\
\hline Sr. \# & Author(s) Full Name & Contribution to the paper & Author(s) Signature \\
\hline 1 & Muhammad Zubair & 1st Author & \\
\hline 2 & Mohsin Ur Rashid & 2nd Author & \\
\hline 3 & Muhammad Azam & 3rd Author & \\
\hline 4 & Hassan Tariq & 4th Author & $\mathbb{H}$ \\
\hline 5 & Syed Salman Ali & 5th Author & Sluede \\
\hline 6 & Akhtar Ali Bajwa & 6th Author & \\
\hline
\end{tabular}

